\title{
Critical Incident Stress of Rescue Workers after the Great East Japan Earthquake : With Examining Local Firefighters, Special Rescue Team and Rescue Divers of Japan Coast Guard
}

\author{
Takaaki Usami ${ }^{1)}$, Koubun Wakashima ${ }^{1)}$ and Kazuki Kato ${ }^{2)}$ \\ ${ }^{1)}$ Graduate School of Education, Tohoku University \\ 2) MACROMILL,Inc
}

ABSTRACT. The purpose of this study was to reveal the general prevalence of PTSD symptoms among rescue workers for two time points: just after the traumatic operation after the Great East Japan Earthquake (Time 1) and seven months or one year after the earthquake (Time 2). We also aimed to examine the effect of the casual conversation about the critical incident on PTSD symptoms and mental condition of rescue workers. The participants were 5 rescue divers and 16 Special Rescue Team (SRT) of Japan Coast Guard (JCG) and 52 local firefighters of disaster area. They answered the questionnaire from November 2011 to March 2012 at voluntary basis. Traumatic stress responses were assessed for two time points (Time 1 and Time 2) with Japanese version of Impact of Event Scale-Revised (IES-R-J, Asukai et al., 2002). The participants answered Time 1 as past reaction, and Time 2 as the current condition. The results revealed that $28.8 \%$ of firefighters, $6.3 \%$ of SRT and $20 \%$ of rescue divers were categorized as high risk of PTSD at Time 1, and $13.5 \%$ of firefighters were categorized as high risk at Time 2 and all SRT and rescue divers of JCG were categorized as low risk at Time 2. The results of this study presented that the conversation about the trauma had no effect on PTSD symptoms and mental condition. However, the conversation about the critical incident would work to improve PTSD symptoms and mental condition since it seems to play a key role at the point in the past when people are sharing the experience.

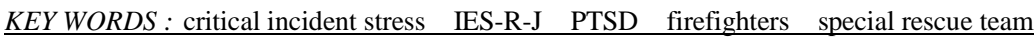

The Great East Japan Earthquake occurred on March 11, 2011 at 14:46 JST. The Eastern part of Japan, from Tohoku to Kanto region, was severely damaged by the 9.0 magnitude earthquake. The earthquake triggered powerful tsunami waves that reached heights approximately up to eight to nine meters

CORRESPONDENCE TO USAMI, Graduate School of Education, Tohoku University, 27-1 Kawauchi, Aoba-ku, Sendai-city, 980-8576, Japan.

E-mail: ijbf@nfbt.org throughout and travelled up to six kilometers from the coastline of Tohoku and Kanto region. After the issue of tsunami warning, firefighters (both professional and volunteer), police officers, and local government officials guided victims to evacuate from coastal area. Some of them injured or perished while on the duty. Firefighters were one of the main professional rescue workers operating after the disaster. A total of 28,600 firefighters across the country, up to 6,100 at one point, have come to work for rescue service and security operation at disaster area including evacuated area of nuclear plants. 
The Japan Coast Guard (JCG) also conducted the rescue service and port reconstruction as a part of their duty.

It has been widely recognized the importance to work on the critical incident stress (CIS) of rescue workers after the accident of Air Florida in 1982 (e.g., Every \& Mitchell, 1997). Following events such as Gulf War, world trade center bombing and September 11 attacks have highlighted the CIS on professional rescue workers. In Japan, the Hanshin Earthquake in 1995 has led people to consider stress measure as an indispensable issue among rescue professionals. The findings on CIS of rescue professionals have piled up in Japan since the earthquake (Hyogo Institute for Traumatic Stress, 2000; Tanouchi, 2005; Japan local government employee safety and health association, 2006; Ohoka et al., 2006; Matsui, Hatanaka \& Maruyama, 2011). However, both researchers and practitioners have not come to any conclusions on the issue of the effect of casual conversation about the traumatic experience on PTSD symptoms.

In this study, we conducted a questionnaire research on professional rescue workers who have engaged in rescue operation for the Great East Japan Earthquake. The participating professionals were 66 firefighters in Sendai city, the nearest major city to the earthquake, all rescue divers of Second Regional JCG, and all Special Rescue Team (SRT) of Third Regional JCG. The participants answered on the items of (1) PTSD symptoms with Japanese version of Impact of Event Scale-Revised (IES-R-J, Asukai et al., 2002), (2) the amount of casual conversation about the critical incident, the operation after the Great East Japan Earthquake, (3) the change of mental condition because of the conversation. Both firefighters in Sendai city and rescue divers of JCG in this research were the victims of the disaster, who resided the area.

Because we did not conduct this study with large-sized population, we applied the analysis adopted from prior studies to compare our results with those of prior studies conducted with large-scale population (Hyogo Institute for Traumatic Stress, 2000; Matsui et al., 2011).

\section{Methods \\ Procedures}

We conducted a questionnaire research on firefighters in Sendai city, rescue divers of second regional JCG, and SRT of third regional JCG, all of whom have had operation for the Great East Japan Earthquake at October of 2011. We distributed the questionnaire of firefighters from company network and collected them later at October of 2011. We sent and collected them via mail for SRT at October of 2011 and rescue divers at March of 2012, respectively.

\section{Research participants}

The participants were 66 firefighters in Sendai city, all of 36 SRT of third regional JCG, and all of five rescue divers of second regional JCG. All of them participated at voluntary basis. We limited the data of participants who indicated that they had operation for the Great East Japan Earthquake. After excluding the 
invalid data, we applied the data of 73 participants (52 firefighters: $M=40.17$ years, range: $22-58$ years, $S D=9.80 ; 16$ SRT: $M=29.00$ years, range: $24-38$ years, $S D=3.03$; and 5 rescue divers: $M=24.60$ years, range: 23-27, $S D=1.52)$ for following analyses. All participants were male.

\section{Measures}

PTSD symptoms

Impact of Event Scale-Revised (IES-R; Weiss \& Marmar, 1997) was applied to assess the reaction of post-traumatic stress during their rescue operation. IES-R is consisted of three subscales: hyper arousal, intrusion, and avoidance. Japanese translated version of this scale (IES-R-J) has confirmed its validity and reliability (Asukai et al., 2002). Higher score means greater traumatic stress at the point of assessing. Asukai et al. (2002) recommended the cutoff values of $24 / 25$ to screen the high risk population of PTSD. In this study, the participants answered IES-R-J for two points (Time 1 and Time 2). They responded Time 1 as their past reaction and Time 2 as that of the current condition.

\section{Casual conversation about the critical incident}

We applied five partners to have casual conversation about the critical incident. They were family members, friends, lover, colleagues shared the incident (shared colleagues) and colleagues not shared the incident (non-shared colleagues). Participants were asked to rate how much they have had casual conversation about the critical incident. Responses were on Likert-type scale, ranging from "not at all" $=0$ to "very much" $=4$. We coded the response from 0 to 1 as "little" and from 2 to 4 as "talk" for casual conversation with each partner. As for family members, friends and lover, we reduced them into one index, intimates. Participants who had at least one code of "talk" among three different intimates were coded as "talk" with intimates whereas those who had no code of "talk" were coded as "little".

Changes of mental condition because of the casual conversation about the critical incident

We developed the items based on Kawase (1999)'s study of social sharing, which referred as having a conversation about the traumatic experience. Participants were asked to rate how much they have realized the changes of mental condition since having casual conversation about the critical incident. Responses were on Likert-type scale, ranging from "not at all" $=0$ to "very much" $=4$.

\section{Results}

IES-R-J score at Time 1 by occupation of rescue professionals

For the total 52 firefighters, the mean total score of IES-R-J at Time 1 was 20.10 $(S D=17.37)$. A total of 15 participants $(28.8 \%)$ had scores 25 or more points and were classified in the high risk group; the remaining 37 firefighters were categorized into the low risk group with scores less than 24 points. The firefighter's mean scores of each subscale of IES-R-J at Time 1 were $8.50(S D=7.55)$ of intrusion, $6.81(S D=6.44)$ of avoidance, and $4.79(S D=5.10)$ of hyper arousal. For the total 16 SRT, the mean total score of IES-R-J at 
Time 1 was $2.44 \quad(S D=6.10)$. One of 16 participants $(6.3 \%)$ was classified in the high risk group; the remaining 15 firefighters were categorized into the low risk group. The SRT's mean scores of each subscale of IES-R-J at Time 1 were $1.44(S D=3.22)$ of intrusion, 0.75 ( $S D=2.02)$ of avoidance, and $0.25(S D=1.00)$ of hyper arousal. For the total five rescue divers, the mean total score of IES-R-J at Time 1 was $10.40(S D=10.88)$. One of five participants (20.0\%) was classified in the high risk group; the remaining four rescue divers were categorized into the low risk group. The rescue diver's mean scores of each subscale of IES-R-J at Time 1 were $7.80(S D=8.04)$ of intrusion, $1.20(S D=2.17)$ of avoidance, and $1.40(S D=2.07)$ of hyper arousal.

IES-R-J score at Time 2 by occupation of rescue professionals

For the total 52 firefighters, the mean total score of IES-R-J at Time 2 was 10.73 $(S D=12.73)$. A total of 7 participants $(13.5 \%)$ had scores 25 or more points and were classified in the high risk group; the remaining 45 firefighters were categorized into the low risk group with scores less than 24 points. The firefighter's mean scores of each subscale of IES-R-J at Time 2 were $4.35(S D=5.48)$ of intrusion, $3.96(S D=5.82)$ of avoidance, and $2.42(S D=2.91)$ of hyper arousal. For the total 16 SRT, the mean total score of IES-R-J at Time 2 was 1.19 ( $S D=4.23)$. All 16 participants were classified in the low risk group. The SRT's mean scores of each subscale of IES-R-J at Time 2 were $0.63(S D=2.00)$ of intrusion,
$0.38(S D=1.50)$ of avoidance, and 0.19 $(S D=.75)$ of hyper arousal. For the total five rescue divers, the mean total score of IES-R-J at Time 2 was $3.80 \quad(S D=1.92)$. All five participants were categorized into the low risk group. The rescue diver's mean scores of each subscale of IES-R-J at Time 2 were 2.60 $(S D=2.30)$ of intrusion, $0.60 \quad(S D=.55)$ of avoidance, and $0.60(\mathrm{SD}=.55)$ of hyper arousal.

The PTSD symptom transition from Time 1 to Time 2 by occupation of rescue professionals

Next, we showed the PTSD symptom transition from Time 1 to Time 2. PTSD symptom was categorized into three levels with total score of IES-R-J for both Time 1 and Time 2 , respectively. The three groups were less than 9 points, 10-24 points, and 25 or more points of the total score of IES-R-J. We applied the results of Time 1 and Time 2 in combination as the PTSD symptom transition. The category names are shown at Table 1. We applied the name based on Matsui et al. (2011).

For the total of 52 firefighters, a total of 17 participants (33\%) had less than 9 points both at Time 1 and Time 2 and were classified in the Non Stress group. The second largest proportion with 14 participants were Resolved group (28\%), which showed mild stress with 10-24 points at Time 1 but non stress with less than 9 points at Time 2. Eight participants (16\%) who categorized into Recovered group showed severe stress symptoms at Time 1 with 25 or more points but recovered to no problematic level with 20-24 points at Time2. The two smallest populations were Prolonged 
group and Sustained/Worsened group with six participants (12\%). Prolonged group population had 25 or more points both at Time 1 and Time 2 , which indicated that they suffered severe PTSD symptoms throughout the period. Sustained/Worsened group experienced mild stress symptoms at Time 1 with 10-24 points and sustained or worsen the symptoms at Time 2.

As for 16 SRT, 15 participants (94\%) was classified into Non Stress group; the remaining participant (6\%) was categorized as Recovered group.

Similarly, the three of the total of six rescue divers $(60 \%)$ was classified into Non Stress group; the remaining two participants were categorized as Recovered group (20\%) and Resolved group (20\%), respectively.

Next, we examined whether the PTSD symptoms increased or decreased from Time 1 to Time 2 with all rescue professionals. We excluded the Non Stress group from this analysis because they have never experienced the PTSD symptoms. Before the analysis, we reduced Resolved group and Recovered group into Decreased group; the remaining Sustained/Worsened group and Prolonged group were reduced into Unchanged/Deteriorated group.

The exact binominal test revealed that the population of Decreased group $(n=26)$ was significantly greater than those of Unchanged/Deteriorated group $(n=12)$. The result indicates that most of the rescue workers would become better even when they initially suffered from PTSD symptoms.

The occupational difference of rescue professionals on the experience of the casual conversation about the critical incident

We analyzed the occupational difference of the experience of casual conversation about the critical incident with each conversation partners. The results revealed that there were no occupational differences on the experience of the conversation with three different partners, respectively (intimates: $\chi_{(2)}^{2}=1.32$, n.s.; shared colleagues: $\chi_{(2)}^{2}=1.66, \quad$ n.s.; non-shared colleagues: $\chi_{(2)}^{2}=2.55$, n.s.).

Table 1

The categorization and the category names of the process of PTSD symptoms

\begin{tabular}{ccccc}
\hline & & \multicolumn{3}{c}{ Total score of IES-R-J Time 2 } \\
\cline { 3 - 5 } & $0-9$ points & $10-24$ points & 25 points or more \\
\hline $\begin{array}{c}\text { Total score of } \\
\text { IES-R-J } \\
\text { Time 1 }\end{array}$ & 10-24 points & Resolved & Sustained/Worsened & Sustained/Worsened \\
& 25 points or more & $* 1$ & Recovered & Prolonged \\
\hline
\end{tabular}

Note. $* 1$ indicates no participants were classified into the categories. 


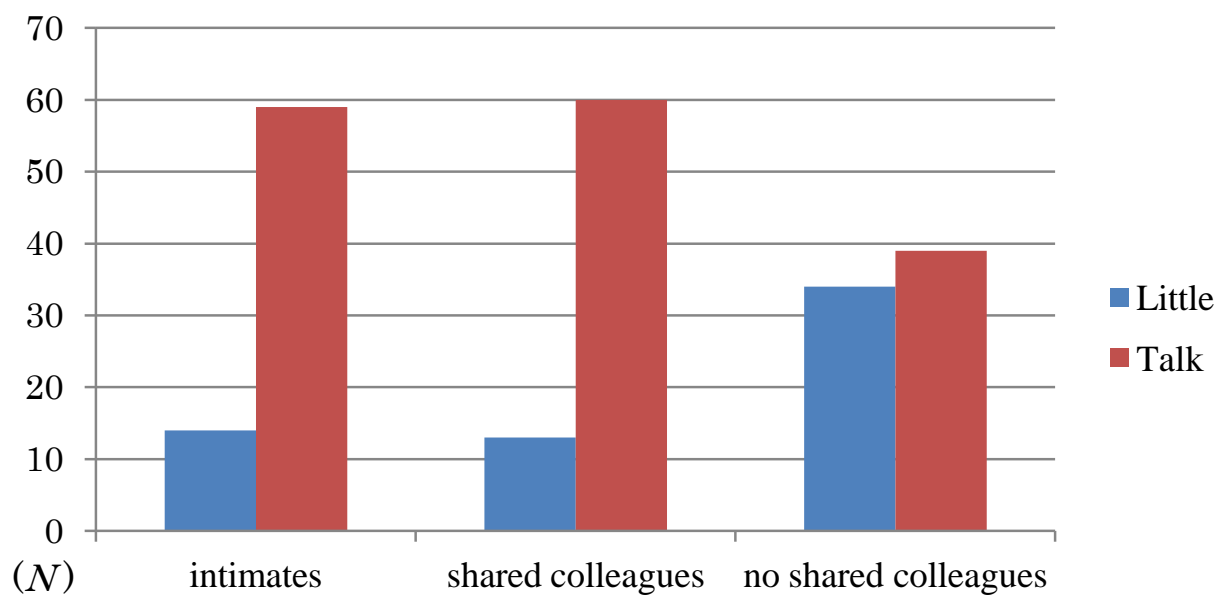

Figure 1. The experience of conversation about the critical incident with three partners among all rescue workers $(N=73)$

The partner difference of casual conversation about the critical incident

Furthermore, we examined the between-partner difference with all rescue professionals. The result showed that the distribution of the experience of casual conversation was different by three partners $\left(\chi_{(2)}^{2}=19.13, \quad p<.01\right)$. Following residual analysis revealed that rescue workers have had a conversation about the critical incident more with intimates and shared colleagues while less with non-shared colleagues (Figure 1).

The scale of changes of mental condition (SCMC) because of casual conversation about the critical incident

We conducted factor analysis with promax and principal factor rotations because we assumed the factor correlations for factors underlying the scale. Four factor solution was supported based on the eigen values of just over one $(6.79,1.92,1.36$, and 1.16). The four factor solution, which explained $74 \%$ of the variance, was preferred with both promax and principal factor rotations of the factor loading matrix because of its previous theoretical support, the 'leveling off' of eigen values on the scree plot after four factors, and the insufficient number of primary loadings and difficulty of interpreting the fifth factor and subsequent factors.

During several steps, a total of five items were eliminated because they did not contribute to a simple factor structure and failed to meet a minimum criteria of having a primary factor loading of .35 or above, and no cross-loading of .35 or above. The items "exchanging information" and "getting a good idea" did not load above .35 on any factor. The items "understanding own feeling", "becoming accepted", "being mentally stable" had cross-loadings on more than two factors.

The factor loading matrix for this final solution is presented in Table 2. 
The items highly loading on first factor were "thinking the incident in an organized way", "thinking the incident in calm way", "making a sensible judgment", "confirming own feeling" and "being objective". We named the first factor as "Sorting out the experience ( $M=11.95$, $S D=3.79, \alpha=.88)$ ". The second factor was "Other's support $(M=6.89, S D=2.51, \alpha=.83)$ " based on the highly loading items: "receiving a consolation", "being listened own feeling", "being supported", and "receiving an advice". The third factor was named "Acceptance $(M=7.23, S D=2.34, \alpha=.86)$ " after the highly loading items: "being agreed", "developing the idea about the incident", and "being sympathized". The last factor was "Feeling better ( $M=8.41, D=3.37, \alpha=.89$ )". The highly loading items were "feeling refreshed", "being distracted", and "not being anxious".

Table 2

Factor loadings and communalities based on a factor analysis with promax and principal factor rotations for 15 items from the Scale of Change of the Mental Condition (SCMC)because of casual conversation about the critical incident $(N=73)$

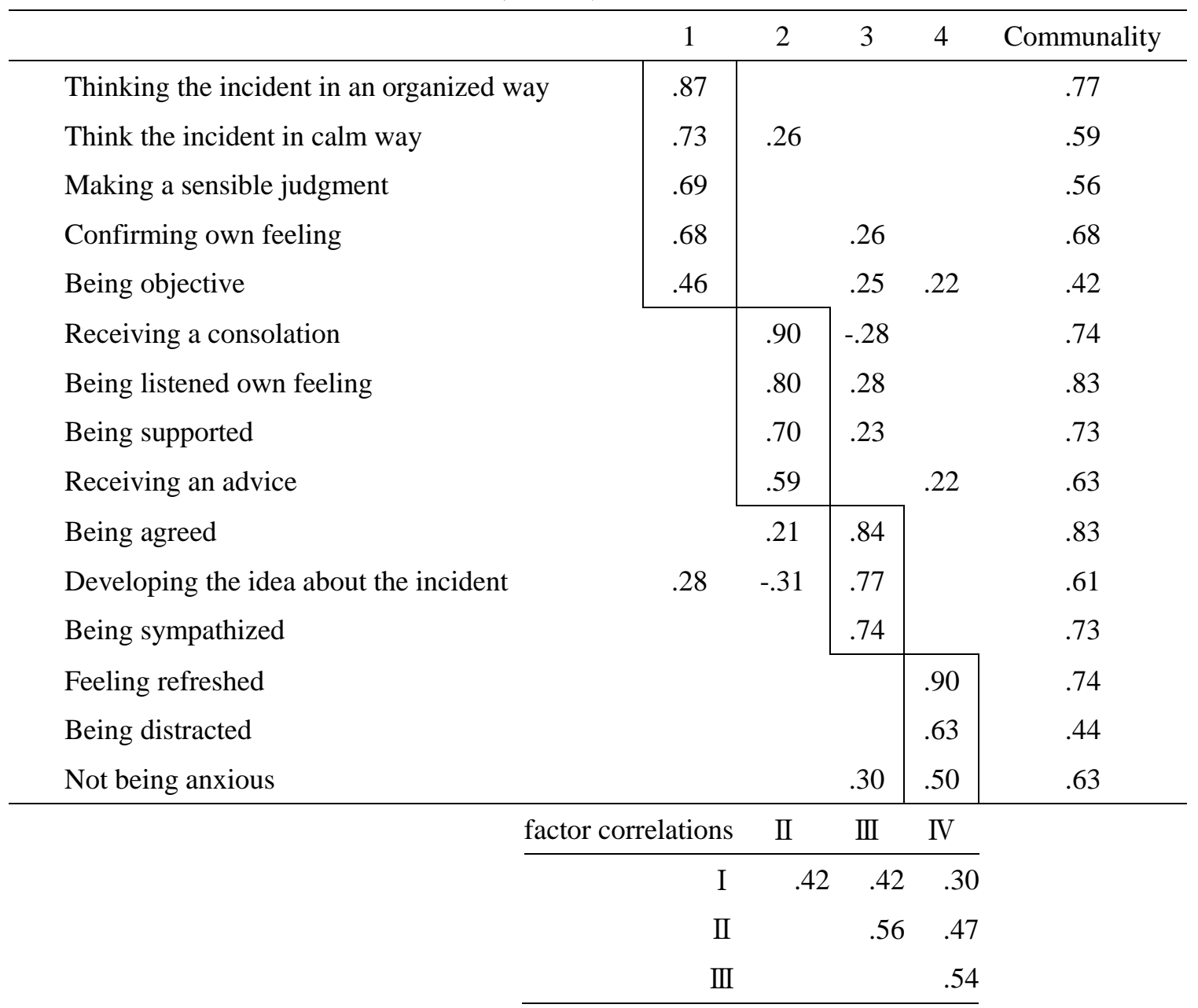

Note. Factor loadings $<.2$ are suppressed. 
The regression analyses on IES-R-J Time 1 IES-R-J Time 2 score difference with all rescue professionals

We conducted a stepwise multi-regression analysis on Time 1 - Time 2 difference of total score of IES-R-J. The predicator variables were three subscales of IES-R-J of both Time 1 and Time 2, the experience of casual conversation with each partner (intimates, shared colleagues and non-shared colleagues), and the four subscales of SCMC ("Sorting out the experience", "Other's support", "Acceptance" and "Feeling better"). The predicator variables explained significant proportion of variance in IES-R-J Time 1 - IES-R-J Time 2 score difference, $R^{2}=.93, F_{(5)}=203.49, p<.001$. The subscales of IES-R-J both at Time 1 and Time 2 significantly predicted the target variable, whereas, the experience of the conversation and SCMC had no significant effects on the IES-R-J Time 1 - IES-R-J Time 2 score difference. This result indicates that both the experience of the conversation and the psychological effects of the conversation have no significant influence on the PTSD symptom process (Table 3).

Similarly, we conducted stepwise multi-regression analyses on IES-R-J Time 1 IES-R-J Time 2 score difference of three subscales of IES-R-J, respectively (IES-R-J Time 1 - IES-R-J Time 2 intrusion, IES-R-J Time 1 - IES-R-J Time 2 avoidance and IES-R-J Time 1 - IES-R-J Time 2 hyper arousal). the predicator variables were the experience of the conversation with each partner(intimates, shared colleagues and non-shared colleagues), and the four subscales of SCMC ("Sorting out the experience", "Other's support", “Acceptance" and "Feeling better").

The predicator variables explained significant proportion of variance in Time 1 Time 2 score difference for each subscale of IES-R-J (intrusion: $R^{2}=.57, F_{(1)}=95.58$, $p<.001$; avoidance: $R^{2}=.27, F_{(1)}=28.21$, $p<.001$; hyperarousal: $R^{2}=.75, F_{(1)}=212.25$,

Table 3

Summary of multiregression analysis for variables predicting the difference of IES-R-J Time 1 IES-R-J Time $2(N=73)$

\begin{tabular}{lclc}
\hline & $B$ & $S E B$ & $\beta$ \\
\hline intrusion Time 1 & 1.15 & 0.09 & .95 \\
intrusion Time 2 & -1.25 & 0.12 & -.69 \\
hyper arousal Time 1 & 1.20 & 0.14 & .64 \\
hyper arousal Time 2 & -1.72 & 0.24 & -.51 \\
avoidance Time 1 & 0.37 & 0.08 & .26 \\
$R^{2}$ & & & .93 \\
$F$ & & 203.49 & \\
\hline
\end{tabular}


$p<.001$.). The results also revealed that Time 1 IES-R Time 2 score differences of each subscale of IES-R-J were significantly predicted by the subscale of Time 1: Time 1 Time 2 score differences of intrusion was predicted by intrusion Time 1 ( $\beta=.76$ ), Time 1 Time 2 score differences of avoidance was predicted by avoidance Time $1 \quad(\beta=.53)$, and Time 1 - IES-R Time 2 score differences of hyperarousal was predicted by hyperarousal Time $1(\beta=.87)$. These results illustrate that the process of the each symptom also has no significant influence from the experience of the conversation and the mental condition.

The regression analyses on changes of mental condition with all rescue professionals

Aiming to examine the effect of experience of casual conversation about the critical incident on mental condition, we conducted a stepwise multi-regression analysis on total score of SCMC. Predicator variables were the experience of the conversation with each partner (intimates, shared colleagues and non-shared colleagues). The predicator variables explained significant proportion of variance in total score of SCMC $\left(R^{2}=.05, F_{(1)}\right.$ $=4.65, p<.05)$ although the value of $R^{2}$ was quite low. Considering the low value of $R^{2}$, we just report significant predicator variables without further interpretation. The experience of the conversation with non-share colleagues significantly predicted the change of mental condition $(\beta=.25)$.

Next, we also conducted stepwise multi-regression analyses on four subscales of
SCMC ("Sorting out the experience", "Other's support", "Acceptance" and "Feeling better"). Predicator variables were the experience of the conversation with partners (intimates, shared colleagues and non-shared colleagues). As with the case of the analysis on the total score of SCMC, The predicator variables explained significant proportion of variance in each subscale of SCMC with low $R^{2}$ value, respectively (Sorting out the experience: $R^{2}$ $=.05, F_{(1)}=4.71, p<.05$; Other's support: $R^{2}$ $=.07, F_{(1)}=6.37, p<.05$; Acceptance: $R^{2}=.08$, $F_{(1)}=7.50, p<.01$; Feeling better: $R^{2}=.03, F_{(1)}$ $=0.63$, n.s.). Once again, we just report significant predicator variables without further interpretation because of the low value of $R$. The experience of the conversation with non-shared colleagues was significant predicator of "Sorting out the experience" $(\beta=.25)$ and "Other's support" $(\beta=.29)$. Moreover, "Acceptance" was significantly predicted by the conversation with shared colleagues $(\beta=.31)$.

Given that low $R^{2}$ value, we can indicate that the experience of the conversation about the critical incident has no significant effect on mental condition.

\section{Discussions}

We revealed the general prevalence of PTSD symptoms among rescue workers at two points: just after the critical incident and seven months or one year after the Great East Japan Earthquake. We also obtained the results that the experience of casual conversation about the incident was not predicted by both PTSD 
symptoms and mental condition. We give some considerations on the results at this section.

\section{IES-R-J score by the occupation}

We obtained the score of IES-R-J at two points: just after experiencing of the critical incident (Time 1) and seven months to one year after the operation (Time 2). The response of Time 1 was drawn as retrospective answer. Prior studies (Hyogo Institute for Traumatic Stress, 1999: Matsui et al., 2011) have applied the same methodology to assess PTSD symptoms. However, future studies should be examined the reliability of the retrospective data on PTSD symptoms.

Hyogo Institute for Traumatic Stress (1999) reported the percentage of high risk population of PTSD among firefighters at two points: (1) 13 months and (2) four and a half year after the Hanshin Earthquake. The researchers classified the participants as high risk with the 20 points or higher of the total score of IES for 13 months later and 25points or higher of the total score of IES-R-J for four and a half year later, respectively. At 13 months later, the amount of $15.9 \%$ of local firefighters who lived in the affected area was categorized into high risk population of PTSD. As for the firefighters deployed from other areas at the same point in time, high risk PTSD symptoms appeared at the total of $4.9 \%$ of them with early stage deployment and $4.2 \%$ of them with latter stage deployment. Hyogo Institute for Traumatic Stress (1999) also revealed that high risk population of PTSD varied among the firefighters who had experienced different operation at four and a half year after the earthquake. High risk PTSD symptoms appeared to $16.3 \%$ of firefighters with high level of exposure, who had engaged in field operation and reported severe mental strain after facing the critical incident, $12.4 \%$ of those who have had no field operation, $5.8 \%$ of newly employed workers without experiencing the operation on the Hanshin earthquake, and $4.1 \%$ of those who with low level of exposure, who have had engaged in field operation and reported no severe mental strain after facing the critical incident. The mean score of intrusion subscale was higher than that of both avoidance and hyper arousal subscales among the firefighters with different operation experience.

Moreover, Hyogo Institute for Traumatic Stress (1999) presented the process of PTSD symptoms among firefighters with high level of exposure. The approximately $60 \%$ of them had the symptom at three month after the earthquake, and $43.2 \%$ at half year later, $27.2 \%$ at a year later, $15.9 \%$ at two years later and $8.7 \%$ at the four and a half year later, respectively.

The results of this study showed that the $13.5 \%$ of firefighters was classified as high risk of PTSD at seven months after the Great East Japan Earthquake. No rescue divers and SRT exhibited severe PTSD symptoms at seven months (SRT) or one year (rescue divers) after the earthquake. A prior study revealed that local firefighters who lived in the disaster area had more risk of PTSD after the Hanshin Earthquake (Hyogo Institute for Traumatic Stress, 2000). We can imply that firefighters and 
rescue divers of this study have higher risk of PTSD because they lived in the affected area. We can also point out that most Japanese recognized PTSD for the first time at the Hanshin Earthquake. Inadequate knowledge of the symptom resulted in exaggerated news coverage, which led to more people to rate them as high risk of PTSD after the Hanshin Earthquake. On the contrary, the media might handle the PTSD symptom more adequately after the Great East Japan Earthquake, which resulted in less high risk population of PTSD. Meanwhile, we should mention that there was no high risk population of PTSD among rescue divers in this study even though they were also local residents. We can interpret the result based on the fact that the rescue divers of this study were in their twenties. They were younger than local firefighters and might have damaged their private properties and family less than the firefighters have done.

Next, we examined the process of PTSD symptoms by occupation of rescue professionals. A previous study investigated the critical incident of the firefighters within the ten years remembering back from the point of research and the pattern of the process of the PTSD symptoms from the time when they experienced it to the present (Matsui et al., 2011). Matsui et al. (2011) presented the distribution of process of PTSD symptom among firefighters who had experienced critical incident: Non Stress group (65.7\%), Resolved group (16.8\%), Recovered group (2.1\%), Late onset group (6.8\%), Worsened group (7.2\%), and Prolonged group (1.4\%). For the total of 52 firefighters of this study, 33\% of them were classified as the Non Stress group, 28\% as Resolved group, $16 \%$ as Recovered group, and $12 \%$ as Prolonged group and $12 \%$ as Sustained/Worsened group. As for 16 SRT of this study, $94 \%$ of the participants were classified into Non Stress group; the remaining participant was categorized as Recovered group. Similarly, the most $(60 \%)$ of the rescue divers of this study was categorized into Non Stress group; the remaining two participants were categorized as Recovered group and Resolved group, respectively. We can argue that No Sustained/Worsened or Prolonged group among SRT and rescue divers resulted from the fact that they were still young (SRT: 29.00 years of age, range: 24-37; rescue divers: 24.60 years of age, range: 23-27). This argument might be supported by the result of Matsui et al. (2011) that the young firefighters generally did not suffered severe PTSD symptoms and their prognosis was mostly favorable. While some prior findings indicated that there are some cases of late onset of PTSD (Matsui et al., 2011), it is more psychologically understandable that the PTSD symptom resulted from the critical incident would develop after a short period of time. Our research has already revealed that the current stress symptom mostly results from the current factors rather than the past ones (Wakashima, Kozuka, Itakura, \& Usami, 2011). Therefore, cases of late onset of PTSD would be developed by maladaptation to the workplace or worsened human relationship after both personal and environmental changes because of 
the critical incident.

This study also showed the result that most of rescue workers experiencing PTSD symptom at Time 1 relieved their symptoms at Time 2. We can maintain that PTSD symptoms generally tend to weaken as time goes.

\section{Casual conversation partners}

All rescue workers have experienced casual conversation about their critical incident more with intimates and shared colleagues while less with non-shared colleagues. The results might reflect the difference of frequency of daily interaction.

The association of IES-R-J score with the experience of casual conversation about the critical incident and the mental condition

Prior studies have not reached the conclusion on the effect of the debriefing on PTSD symptoms. Some of them support the advantage (Chemtob, Tomas, Law, \& Cremniter, 1997), but others do not (Hytten \& Hasle, 1989; Bisson \& Deahl, 1994; Deahl, Gillham, Thomas, Searle \& Srinivasan, 1994). In Japan, there is a report on the effectiveness of informal debriefing for PTSD symptom (Hyogo Institute for Traumatic Stress, 1999). The report revealed that people rated lower IES score at 13 months after the earthquake than they did at three months after the disaster. However, we can point out that the research is not the evidence of effect of informal debriefing on PTSD symptoms because the decreasing PTSD symptoms could result in less conversation about the incident. Our results showed the no association between casual conversation about the critical incident and IES-R-J score. Hence, we did not gain the support for effectiveness of informal debriefing on PTSD symptoms.

Although the fact that we obtained the results that there is no association between casual conversation about the critical incident and IES-R-J score, there is a room for casual conversation to be an influential factor for PTSD symptoms. We measured conversation about the trauma experience but we can also measure conversation about the PTSD symptoms resulted from the experience. PTSD symptoms are relatively similar among victims even though each of their traumatic experiences is unique. Therefore, it has large impact on treatment of PTSD to examine the effect of casual conversation about the PTSD symptoms.

The association of the experience of casual conversation about the critical incident with mental condition

Given that low $R^{2}$ value, our results also indicate that experience of casual conversation about the critical incident has no significant effect on mental condition. Based on this result as well as the result of the conversation on PTSD symptoms, we may argue that the informal debriefing about critical incident has no effect on PSTD symptoms and mental condition. We need to interpret the result in the light of the fact that research was conducted seven months or one year after the Great East Japan Earthquake and the conversation of the critical incident is a part of daily conversation. Conversation partners in this study (intimates, 
shared colleagues and non-shared colleagues) have ongoing relationship with the participants, which means they have a plenty of opportunity to have conversation. Seven months or one year might be enough periods to shift away from talking about the critical incident to more about the other topics on current life. Considering that the current symptom mostly results from the current factors rather than those of the past (Wakashima et al., 2011), the result of this study might reflect that the current conversation on limitless topics rather than the past conversation on critical incident has an effect on PTSD symptoms and the current mental condition of rescue professionals.

However, we cannot underscore the importance of the conversation about the critical incident. This study indicates that most of the rescue professionals have had the experience of the conversation on the topic with others. To have the experience of conversation means that people was experiencing the conversation as a current event at a point in the past. Given that finding that the current symptom mostly results from the current factors rather than the past (Wakashima et al., 2011). Therefore, the conversation about the critical incident could contribute to PTSD symptoms and mental condition at a point in the past when people are sharing the experience.

\section{Conclusions}

This study clarified the general tendency and the process of rescue workers' PTSD symptoms just after experiencing a critical incident during their operation (Time 1) and seven months or one year after the Great East Japan Earthquake. We also examined the association of casual conversation about the critical incident with PTSD symptoms and mental condition of rescue professionals. The results indicated that the conversation has no significant influence on both PTSD symptoms and their mental condition. Given that PTSD symptoms gradually become weakened, the conversation about the critical incident could contribute to PTSD symptoms and mental condition at a point in the past when people are sharing the experience but not in the present where people talk more on the other topics.

\section{References}

Asukai, N., Kato, H., Kawamura, N., Kim, Y., Yamamoto, K., Kishimoto, J., \& Nishizono, M. A.(2002). Reliability and validity of the Japanese-language version of the Impacr of Event Scale-Revised(IES-R-J). Journal of Nervous and Mental Disease, 190, 175-182.

Bisson, J. I., \& Deahl, M. P. (1994). Psychological debriefing and prevention of post-traumatic stress. British Journal of Psychiatry, 165, 717-720.

Chemtob, C. M., Tomas, S., Law, W., \& Cremniter, D. (1997). Postdisaster psychosocial intervention: A field study of the impact of debriefing on psychological distress. American Journal of Psychiatry, 154, 415-417.

Deahl, M., Gillham, A. B., Thomas, J., Searle, M. M., \& Srinivasan, M. (1994). 
Psychological sequelae following the Gulf War. Factors associated with subsequent morbidity and the effectiveness of psychological debriefing. British Journal of Psychiatry, 165, 60-65.

Everly, G. S. Jr., \& Mitchell, J. T. (1997). Critical incident stress management. A new era and standard of care in crisis intervention 2nd edition. Ellicott City, MD: Chevron Publishing Corporation.

Hyogo Institute for Traumatic Stress (1999). Hijouzitai Stress to Saigaikyuzyosya no Kenkozyotai nikansuru Cyosakenkyu Hokokusyo. (A report of critical incident stress and health condition in rescue professionals). Kobe: Hyogo Institute for Traumatic Stress. [in Japanese] (兵庫県精 神保健協会こころのケアセンター （1999），非常事態ストレスと災害救援者 の健康状態に関寸る調查研究報告書一 阪神・淡路大震災が兵庫県下の消防職員 に及ぼした影響一。

Hyogo Institute for Traumatic Stress (2000). Saigaikyuzyosya no Shinriteki Eikyo nikansuru Cyosakenkyu Hokokusyo (A report of the mental health of rescue professionals). Kobe: Hyogo Institute for Traumatic Stress. [in Japanese] (兵庫県精 神保健協会こころのケアセンター (2000). 災害救援者の心理的影響に関す る調查研究報告書一阪神・淡路大震災が 消防職員に及ぼした長期的影響一).

Hytten, K., \& Hasle, A. (1989). Fire fighters: A study of stress and coping. Acta Psychiatrica Scandinavica, 80, Supplementum, 50-55.
Japan local government employee safety and health association (2006). Shoubou Syokuin no Genba nikakawaru Stress Taisaku Follow-up Kenkyukai Houkokusyo (A report of measure of stress on firefighters). Tokyo: Japan local government employee safety and health association. [in Japanese] (財団 法人地方公務員安全衛生推進協会 (2006)，消防職員の現場に係わるストレ ス対策フォローアップ研究会報告書).

Kawase, T. (1999). Kanjo wo Kataru Riyu (The reason to talk). Bulletin of Miyazaki Municipal University Faculty of Humanities 7(1), 135-149. [in Japanese] (川瀬隆千 (1999). 感情を語る理由：人はなぜネガ ティブな感情を他者に語るのか。宮崎公 立大学人文学部紀要 7(1), 135-149).

Matsui, Y., Hatanaka, M. \& Maruyama, S. (2011). Late-onset critical incident stress in fire fighter in Japan. Japanese Journal of Interpersonal and Social Psychology, (11), 43-50. [in Japanese] (松井 豊 - 畑中美 穂・丸山 晋 (2011). 消防職員における 遅発性の惨事ストレスの分析. 対人社会 心理学研究 (11) , 43-50).

Ohoka, Y., Tsuzimaru, S., Ohnishi, R., Fukuyama, H., Yazima, J., \& Maeda., M.(2006). A report on actual conditions of mental health for firefighters. Bulletin of faculty of literature, Kurume University: Social Walfare, 6, 85-95. [in Japanese] (大 岡由佳 - 辻丸秀策 - 大西 良・福山裕夫 矢島潤平・前田正治(2006). 消防隊員の メンタルヘルスについての実態調査報 告. 久留米大学女学部紀要, 社会福祉学 科編 6, 85-95). 
Tanouchi, K. (2005). A survey on critical incident stress experienced by disaster response professionals: Fire-fighting personnel. Journal of Azabu Universiy, 21-32. [in Japanese] (田之内厚三 (2005). 職業的災害救助者の惨事ストレス調査： 消防職員を対象として. 麻布大学雑誌, 21-32.)

Wakashima, K., Kozuka, T., Itakura, N., \& Usami, T. (2011). Simultaneous and cumulative family relationship: Examining with ICHIGEKI. International Journal of Brief Therapy and Family Science, 1(2), 104-110.

Weiss, D.S., \& Marmar, C.R. (1997). The Impact of Event Scale-Revised. In Wilson, J.P., \& Keane, T.M. (Eds.), Assessing psychological trauma and PTSD: A practitioner's handbook (pp. 399-411). New York: Guilford Press. 